\title{
TRANSNATIONAL SOLIDARITY AMONG EUROPEAN CITIES ${ }^{1}$
}

\author{
Helle Krunke and Katarina Hovden
}

\begin{abstract}
'Cities today are the laboratories where many innovative solutions are emerging to address the biggest economic, social and environmental challenges facing our societies today', David O'Sullivan, the European Union's Ambassador to the United States.
\end{abstract}

\section{INTRODUCTION: BUILDING TRANSNATIONAL SOLIDARITY BETWEEN CITIES}

In this chapter, we study the growing phenomenon of transnational cooperation between and among cities in Europe. This cooperation is driven by other actors than state-level actors, is (or at least claims to be) closer to the citizens, and is based on specific challenges facing cities in different countries. Central to the development is an increased legal and political role for the city transnationally. In a moment with multiple challenges to solidarity, our aim is to assess whether cooperation initiatives between and among cities in Europe could be a means through which to create or contribute towards a European transnational solidarity. Our focus is on cities within the territorial space of the European Union. That being said, the phenomenon of intercity cooperation is by no means confined to Europe (or to the European Union) and we therefore include prominent global initiatives in which European cities participate at the end of the chapter.

In 2016, more than half of the global population lived in cities. By 2030, the United Nations has projected that 6 out of 10 people will be urban dwellers. ${ }^{2}$ Europe is certainly no exception to this global trend; already in 1950, over half of the European population lived in urban areas. ${ }^{3}$ Since then, there has been a steady increase in the concentration of populations in the urban relative to the rural

\footnotetext{
${ }^{1}$ This project has received support and funding from the European Union (EU) Horizon2020 project DEMOS, grant No 822590. This article is an early version of a book chapter, which will be published in Helle Krunke, Hanne Petersen and Ian Manners (eds.): Transnational Solidarity. Concept, Challenges and Opportunities, Cambridge University Press, 2020 (forthcoming).

* The authors wish to thank Project Student Benjamin Vynne Muschinsky for assisting with search of legal sources, literature and information for this chapter.

${ }^{2}$ United Nations, Economic and Social Council, 'Report of the Secretary-General. Progress towards the sustainable development goals' (2016) E/2016/75, available at: https://unstats.un.org/sdgs/files/report/2016/secretary-general-sdgreport-2016--en.pdf (accessed 15 March 2019).

${ }^{3}$ Urban Europe, 'Statistics on cities, towns and suburbs' (Brussels: Eurostat 2016), p. 8.; United Nations, Department of Economic and Social Affairs, Population Division, 'World urbanization prospects: The 2014 revision' (2015) ST/ESA/SER.A/366, available at https://esa.un.org/unpd/wup/publications/files/wup2014-report.pdf (accessed 15 March 2019).
} 
areas, totalling $73 \%$ population in 2014 . By 2050 , the European Union projects that $80 \%$ population will live in urban areas. ${ }^{4}$

The dense accumulation of populations in cities gives rise to numerous challenges - ecological, social, and economic. Cities, because they house such vast proportions of the population, are inevitably responsible for a large proportion of the human strain on natural systems: water, land, habitats, species populations, and more. Cities are also vulnerable. While pressures on infrastructure, resources, and limited space are by no means new challenges for cities, the contested and unpredictable era of climate change and natural disasters amplifies existing challenges. In the 2018 Global Risks Report produced by the World Economic Forum, transnational environmental threats dominated. 'Extreme weather events', 'natural disasters', and the 'failure of climate-change mitigation and adaptation' appeared in both the list over the top five most likely and the top five most impactful global risks. ${ }^{5}$ These are all risks that pose particular challenges for cities.

Many of the challenges so far discussed are non-national by their very nature, highlighting the need for transnational cooperation and mutual support - possible building blocks, one might think, for transnational solidarity. Yet, if we look at Europe, the geographical focus of our chapter, we have the impression that the reality of interconnection and interdependence is not always translating to an actual feeling of solidarity between people. Instead, solidarity in Europe appears to be challenged, as evidenced by the growth in populist movements and isolationist agendas, and the falling support for the European Union in some Member States. The reasons therefore are no doubt many, and it is not the aim of this chapter to suggest what they might be. What we can suggest is that the presumed (or imposed) bonds of solidarity between the Member States of the European Union, as laid down in the Treaties ${ }^{6}$ (the preamble to the Treaty on the Functioning of the European Union for example announces an intention 'to confirm the solidarity which binds Europe and the overseas countries'7), no longer appear to be enough (if they ever were) to build coherence in Europe.

\footnotetext{
${ }^{4}$ Urban Europe, 'Statistics on Cities, Towns and Suburbs', p 8.

${ }^{5}$ World Economic Forum, The Global Risks Report 2018 (2018) 13th edition, available at: http://www3.weforum.org/docs/WEF_GRR18_Report.pdf (accessed 15 March 2019).

${ }^{6}$ The Treaty on European Union (TEU) mentions solidarity fourteen times and the Treaty on the Functioning of the European Union (TFEU) ten times, in the preamble and operative parts of the treaties.

${ }^{7}$ Consolidated version of the TFEU [2008] OJ C115/47, preambular postulation 8.
} 
Against this background, cities are emerging (or, perhaps more accurately, re-emerging ${ }^{8}$ ) as global actors and participants in global governance. Re-emerging because, as Pluijm and Melissen remind us, 'city diplomacy' - which they define as 'the institutions and processes by which cities, or local governments in general, engage in relations with actors on an international political stage with the aim of representing themselves and their interests to one another' ${ }^{9}$ - is not new; such '[d]iplomacy... existed before the existence of states ${ }^{10}{ }^{10}$ As we will discover later in the chapter, cities have been self-advocating for their greater involvement in international politics, most prominently in matters related to sustainable development. Successful, it turns out, since cities are explicitly encompassed by the United Nations Sustainable Development Goals and Agenda 2030. Goal 11 is to '[m]ake cities and human settlements inclusive, safe, resilient and sustainable'. ${ }^{11}$ More than that, the SDGs and accompanying Agenda 2030 mainstream the idea of multi-level stakeholder participation in achieving the global goals, including by the local levels of government. ${ }^{12}$ To that end, 'Local2030' is one of the partnerships set up under the SDGs, aiming to bring the wide gamut of stakeholders together 'to collaboratively develop and implement solutions that advance the SDGs at the local level [emphasis added]' ${ }^{13}$

\section{COSMOPOLITAN BIG CITIES VS. SMALL TOWNS IN THE PROVINCES}

Let us return for a moment to the population statistics that were projected at the outset, for they do not tell the full story. While the biggest capital cities, such as London and Paris, are expected to bear a disproportionate portion of the projected increase, the smallest cities in Europe, those that

\footnotetext{
${ }^{8}$ Janne E Nijman, 'Renaissance of the city as global actor: The role of foreign policy and international law practices in the construction of cities as global actors' in The transformation of foreign policy: Drawing and managing boundaries from antiquity to the present (Oxford: Oxford University Press 2016).

${ }_{9}^{9}$ R.V.D. Pluijm and J. Melissen, 'City diplomacy: The expanding role of cities in international politics' (The Hague 2007), p. 6.

${ }^{10}$ Ibid., p 5.

${ }^{11}$ United Nations Economic Commission for Europe, 'Day of cities', available at: http://www.unece.org/housing/dayofcities.html (accessed 15 March 2019); United Nations Economic Commission for Europe, 'Day of cities provisional agenda', available at: http://www.unece.org/fileadmin/DAM/hlm/Meetings/2019/04_8_Day_of_Cities/Day_of_Cities_Provisional_Agenda_U pdated_20.02_1_.pdf (accessed 15 March 2019).

${ }^{12}$ United Nations, General Assembly, 'Transforming our world: The 2030 agenda for sustainable development' (2017) A/RES/70/1, available at: http://www.un.org/en/development/desa/population/migration/generalassembly/docs/globalcompact/A_RES_70_1_E.p df (accessed 15 March 2019), para 45.

${ }^{13}$ United Nations, 'Local2030' (Partnerships for the SDGs: Global registry of voluntary commitments \& multistakeholder partnerships), available at: https://sustainabledevelopment.un.org/partnerships/local2030 (accessed 15 March 2019), para. 52, emphasis added.
} 
barely qualify for city status, may be more prone to population drains. ${ }^{14}$ People tend to migrate to the city, as they have historically done, 'in search of a job and an improved quality of life'. ${ }^{15}$ Thus, the discrepancies in population trends between cities of different sizes may be explained by the fact that economic activities tend to be highly concentrated in large cities. ${ }^{16}$ Moreover, it is often the case that countries have just one, or a few, such mega-hub(s) of economic activity - most obviously, the capital city. It is unlikely that this will change in the years to come. In fact, deindustrialisation or post-industrialisation, that is to say, 'the transition that has occurred in advanced industrial nations from a manufacturing-based to services-driven economy', ${ }^{17}$ may encourage an even greater concentration of economic activities in large or capital cities. In the era of the so-called knowledge economy, in which there is a 'greater reliance on intellectual capabilities than on physical inputs or natural resources', proximity to the land or resources beyond the city is simply not a necessity for a vast proportion of jobs. ${ }^{18} \mathrm{With}$ these statistics and projections, we uncover one of the reasons why cities may be encouraged to cooperate with other cities across borders: simply, they may find that they have more in common with their transnational counterparts than those within their own country.

A city may find it has more in common with cities in other countries, which for example are of a similar size and climate, or which have similar geographical features, than it does cities in its own country. Linking cities together in transnational dialogue might thus be a tool with which to strengthen the solidarity of EU citizens and thereby a contribution to EU solidarity as such. However, it is important to be aware that there currently seems to be a tension between, on the one hand, capitals and big cities and, on the other hand, smaller cities and rural areas in the countryside. Nations are split between cosmopolitan citizens who think solidarity across borders and citizens who turn towards the nation state as the main ground for solidarity. We see a general trend of globalized cities and more inward-looking provinces in the countryside. It is a trend across Europe, but we also see it in many countries outside Europe, for instance in the US. It finds its expression through among others national referenda and elections, and in elections for the EU Parliament. At

\footnotetext{
${ }^{14}$ European Commission, 'Eurostat Regional Yearbook: 2018 edition' (Brussels: Eurostat, 2018), p. 178, available at: https://ec.europa.eu/eurostat/documents/3217494/9210140/KS-HA-18-001-EN-N.pdf/655a00cc-6789-4b0c-9d6deda24d412188 (accessed 15 March 2019).

15 Ibid.

${ }^{16}$ Ibid.

${ }^{17}$ W.W. Powell and K. Snellman, 'The knowledge economy', Annual Review of Sociology, 30 (2004), 199-220, at 201.

${ }^{18}$ Ibid.
} 
the same time, large groups, including the younger generations, refuse to express themselves through the established political system as we have recently seen in the UK Brexit referendum.

What does all of this mean for our study of cooperation between and among cities as a means to build European solidarity? It means that the solidarity crisis in Europe is not only a transnational crisis; it is also a solidarity crisis within different groups in the individual Member States, geographically expressed as a conflict between large cities and provinces. As an example to illustrate the extent of the contrasts: in the Danish elections in 2015, approximately $80 \%$ of the voters in Nørrebro, which is a large district in Copenhagen, voted for the 3 left wing parties, which among others have a strong green focus, while $40 \%$ of the voters in a small town in Jutland at the border to Germany voted in favour of 'Dansk Folkeparti', which is the most right wing party in the Danish Parliament that among other things has a strong focus on migration. Though this might be a particularly polarised example, it still provides a good picture of how deep the distance can be between capitals and small towns, which focus on different challenges. The other side of the coin is that, if cross-border cooperation between cities can be extended not just to cover cooperation between and among big cosmopolitan cities, but also to cover transnational cooperation between small cities, which face the same challenges, then it might actually be possible to establish more transnational solidarity between the citizens of Europe, and perhaps even a richer European discourse on the different challenges, which Europe is facing.

\section{III. $\quad$ STATE-OF-THE-ART AND THE FOCUS OF OUR STUDY}

While the literature has focused on showing the emergence of cities and transnational associations of cities in the international arena, ${ }^{19}$ studying it from a multi-level governance perspective, ${ }^{20}$ as part of a globalization trend, ${ }^{21}$ in light of international politics, ${ }^{22}$ and through an international law prism where cities increasingly take part in transnational legal processes, ${ }^{23}$ we focus on the possible role

\footnotetext{
${ }^{19}$ Y. Blank, 'The city and the world', Columbia Journal of Transnational Law, 44 (2006), 868-931; Y. Blank, 'Localism in the new global legal order', Harvard International Law Journal 47 (2006), 263-281; G.E. Frug and D.J. Barron, 'International local government law', The Urban Lawyer, 38 (2006), 1-62.

${ }^{20}$ K. Kern and H. Bulkeley, 'Cities, Europeanization and multi-level governance: Governing climate change through transnational municipal networks', JCMS: Journal of Common Market Studies, 47 (2009), 309-332.

${ }^{21}$ P.J. Taylor, B. Derudder, P. Saey, and F. Witlox, Cities in Globalization: Practices, Policies and Theories (New York: Routledge, 2006); P.J. Taylor and B. Derudder, World City Network: A Global Urban Analysis (New York: Routledge, 2015).

${ }^{22}$ Pluijm and Melissen, City Diplomacy; N.J. Toly, 'Transnational municipal networks in climate politics: From global governance to global politics', Globalizations, 5 (2008), 341-356.

${ }^{23}$ J. Lin, Governing Climate Change: Global Cities and Transnational Lawmaking (Cambridge: Cambridge University Press, 2018).
} 
of cities in contributing to transnational solidarity in Europe. ${ }^{24}$ In a moment of solidarity crisis, and dwindling support for the traditional political apparatus, we are interested to know whether the city could have a role to play in building transnational solidarity. Since cooperation initiatives between and among cities in Europe connect people across borders in an alternative way to treaties, it seems they could be one way to strengthen European transnational solidarity.

The literature has especially emphasised that cities are closer to the citizens than the state when discussing their emerging role on the international stage. ${ }^{25}$ This is also the reason provided by the cities themselves and international organisations as a justification for the new influence of cities in a global context. City proximity to the challenges felt at the local level, so the argument goes, necessitates their participation in global conversations about the solutions that would adequately and appropriately address those challenges. The principle of subsidiarity is sometimes referred to. It should be noted that the described development is not without critics. For example, it has been put forward that cities alone cannot solve challenges of climate change. ${ }^{26}$ Moreover, Porras cautions that cities, 'despite their democratic credentials... are increasingly losing their strong public government function as traditional public services are privatized and cities begin to resemble private corporations'. ${ }^{27}$

\section{ON CONCEPTS: THE CITY, COOPERATION, AND (TRANSNATIONAL) SOLIDARITY}

This chapter engages with three central concepts: the city, cooperation, and (transnational) solidarity. As the reflections in the former section may have suggested, we want to focus on cities in different sizes. This way we might transgress a common understanding of the city as referring to a quite large town and in some cases even to the centre of a large city. As a minimum, there must be a certain structure and organisation, which allows the city to enter into agreements with other cities abroad. This will normally also mean that we are talking about either a good number of inhabitants and/or an area of a certain size.

\footnotetext{
${ }^{24}$ Theory exists on the special case of 'town twinning', where the collaboration between twin towns is studied empirically through among others interviews. See, for instance, J. Jańczak, 'Town twinning in Europe. Understanding manifestations and strategies', Journal of Borderlands Studies, 32 (2017), 477-495.

${ }^{25}$ I.M. Porras, 'The city and international law: In pursuit of sustainable development', Fordham Urban Law Journal, 36 (2009), 537-601.

${ }^{26}$ Ibid.

${ }^{27}$ Ibid., p. 539.
} 
In the United Nations 2016 Data Booklet on the World's Cities, the following definitions are offered: 28

'Most people can agree that cities are places where large numbers of people live and work; they are hubs of government, commerce and transportation. But how best to define the geographical limits of a city is a matter of some debate. So far, no standardized international criteria exist for determining the boundaries of a city and often multiple different boundary definitions are available for any given city.

One type of definition, sometimes referred to as the 'city proper', describes a city according to an administrative boundary. A second approach, termed the 'urban agglomeration', considers the extent of the contiguous urban area, or built-up area, to delineate the city's boundaries. A third concept of the city, the 'metropolitan area', defines its boundaries according to the degree of economic and social interconnectedness of nearby areas, identified by interlinked commerce or commuting patterns, for example. ${ }^{29}$

Since we are interested in cities as legal entities, which can enter into agreements with other cities abroad, the 'city-proper' definition, with its emphasis on administrative boundaries, is most appropriate for our study. On this view, the city is by no means a single actor; rather, it encapsulates numerous actors that are competent to represent the city in different matters. These actors include local governments, municipalities, city councils, and mayors, to name a few.

Moving on, to cooperation and (transnational) solidarity. Since we are studying the extent to which various cooperation initiatives may aim at, contribute to, or reflect, solidarity, it is apparent that we are operating under the premise that cooperation and solidarity are distinct concepts and that one does not necessarily entail the other. The Oxford Dictionary's definition of cooperation as 'the action or process of working together towards the same end' is descriptive of the manner in which we conceive cooperation. Moreover, it is our view that cooperation is an element of, and one means by which to express, solidarity, but that it is neither necessary nor sufficient for solidarity. That being said, since we are assessing solidarity in relation to cooperation initiatives, we are necessarily exploring the links between the two concepts for the purposes of this chapter.

What about the concept of solidarity, then? Many definitions of solidarity exist; all with a different focus. ${ }^{30}$ Barbara Prainsack's definition of solidarity, which emphasises that solidarity builds on

\footnotetext{
${ }^{28}$ United Nations, Department of Economic and Social Affairs, Population Division, 'The world's cities in 2016 - data booklet' (2016) (ST/ESA/SER.A/392), available at: 1: www.dx.doi.org/10.18356/8519891f-en (accessed 15 March 2019).

${ }^{29}$ Ibid., p 1.

${ }^{30}$ We refer to the discussion of different definitions of solidarity and transnational solidarity in the Introduction and the Concluding Thoughts sections of the book.
} 
practises, is interesting because it opens up for many different practises with a multitude of actors and different kinds of 'costs' (financial, social, emotional, or otherwise). ${ }^{31}$ However, for our purpose we need to add a transnational dimension. Having done so, we reach the following understanding of transnational solidarity: Transnational solidarity signifies practises reflecting a commitment to carry 'costs' (financial, social, emotional, or otherwise) to assist others across borders with whom we recognise similarities in a relevant aspect.

\section{ON METHOD}

The purpose of this chapter is to illuminate transnational cooperation between and among cities in Europe, considering in particular whether such cooperation initiatives could be a means through which to create or contribute towards a European transnational solidarity.

We approach this by first shedding light on the different possible types of city cooperation and their characteristics. Intercity cooperation - in contradiction to interstate cooperation - is carried out at the local level, closer to the citizens, in a more informal way, and often addresses a concrete current challenge for the cities involved in the cooperation (in other words a challenge that is visible and relevant for the local politicians, citizens, and companies).

We are mostly interested in whether the studied intercity cooperation initiatives include an element of transnational solidarity. We do not engage in measuring precisely the extent to which the cooperation initiatives create or contribute to transnational solidarity. The latter could be the object of further study in another research project. Following Prainsack's definition of solidarity, we are looking for a commitment component and a willingness to carry 'costs' of different kinds.

It has not been possible to find and research all initiatives between European cities in this chapter. Instead, we have chosen a selection of case studies. In case study selection, we applied a 'most different' approach: searching for multiple expressions of city cooperation. The idea behind applying a 'most different' criterion is to try to show that transnational solidarity exists in many different forms of cross-border city cooperation. ${ }^{32}$ Besides a 'most different' criterion, we based our selection on the existence of cooperation between cities, the involvement of cities in at least two

\footnotetext{
${ }^{31}$ See B. Prainsack, and A. Buyx, Solidarity in Biomedicine and Beyond (Cambridge: Cambridge University Press, 2017).

${ }^{32}$ Ran Hirschl uses the term 'most different' cases criterion. According to his theory, the purpose is to prove a hypothesis by showing that even if the 'most different' cases are compared, similarities exist as regards the component reflected in the hypothesis. See R. Hirschl, 'The question of case selection in comparative constitutional law', The American Journal of Comparative Law, 53 (2005) 125-156, at 139.
} 
nation states in the cooperation, and a degree of formalisation of the cooperation. After having selected the case studies, we assessed whether they included an element or elements of transnational solidarity. We have structured the case studies into three groupings: initiatives with a European reach, thematic initiatives, and geographically delimited initiatives.

\section{SAMPLING TRANSNATIONAL COOPERATION INITIATIVES BETWEEN EUROPEAN CITIES}

\section{A. Initiatives with a European Reach}

In what follows, we discuss three cooperation initiatives that have a European reach, including not only EU Member States but also countries within the wider geographical space of Europe, and, in the case of the first initiative, also (some of) Europe's neighbours.

\section{1) EUROCITIES}

EUROCITIES was founded in 1986 by the mayors of six large cities: Barcelona, Birmingham, Frankfurt, Lyon, Milan, and Rotterdam. Today, EUROCITIES is a network of more than 140 of Europe's largest cities and over 45 partner cities, collectively governing 130 million citizens across 39 countries. Cities of different sizes participate, but full membership requires cities to be located in the Member States of the EU or the European Economic Area (hereinafter, 'EEA'), to be 'an important regional centre with an international dimension', and usually to have a population of at least 250,000 inhabitants. ${ }^{33}$ For instance, Copenhagen and Aarhus are the only Danish cities to participate (and also the two largest cities in Denmark). Associate membership is open to cities of the same size and character as full members, but which are located outside the EU or EEA, while partner status is available to 'local authorities or organisations that are not eligible for full or associate membership' ${ }^{34}$ Finally, EUROCITIES has a membership category for business partners.

Ultimately, EUROCITIES emphasises its character as 'the main a political platform' for the mayors and leaders of major European cities towards the EU institutions, highlighting that it has been 'making cities' voices heard in Europe since 1986'. ${ }^{35}$ EUROCITIES has a strong focus on how to

\footnotetext{
${ }^{33}$ EUROCITIES, 'Membership categories', available at: http://www.eurocities.eu/eurocities/members/membership_categories (accessed 15 March 2019).

${ }^{34}$ Ibid.

${ }^{35}$ EUROCITIES, 'Why join', available at: http://www.eurocities.eu/eurocities/members/why_join (accessed 15 March 2019).
} 
solve challenges at the local city level, and the organization attempts both to cooperate with the EU and to influence EU law and policy in matters relevant to city governance:

'Well-performing cities and metropolitan areas are crucial not just for the local, regional and national level, but for Europe as a whole. Their performance is critical both to Europe's global competitiveness and to its democratic legitimacy. ${ }^{36}$

Its strategic framework for 2014-2020 identifies the following themes: jobs and sustainable growth, diverse and creative cities, green and healthy cities, smarter cities, and urban innovation. The focus areas are all topics, which try to solve major challenges for cities and the citizens living in them. ${ }^{37}$ They deal with challenges, to which the citizens can relate. ${ }^{38}$ EUROCITIES moreover emphasises the need for cohesion policy as being vital for economic growth and social cohesion across Europe and links it to a need for more EU structural funds to cities.

How close to the citizens does the EUROCITIES cooperation take place? The main purpose seems to be to 'work with all levels of government to ensure cities' interests are taken into account when EU policies affecting local and regional governments are developed' ${ }^{39}$ It also claims that its work with the EU institutions is an effort to 'respond to common issues that affect the day-to-day lives of Europeans'. ${ }^{40}$ Despite working on matters that are close to European citizens, EUROCITIES looks more like an interest group for cities and city actors than it does a network, which is attempting to involve citizens directly across borders. Its objectives confirm this view. EUROCITIES seeks to 'reinforce the important role that local governments should play in a multilevel governance structure', 'shape the opinions of Brussels stakeholders', and ultimately 'shift the focus of EU legislation in a way which allows city governments to tackle strategic challenges at local level' ${ }^{41}$ Thus, it seems that EUROCITIES is more focused on re-balancing the relative power of the city vis-à-vis the nation state than it is connecting citizens of the EU across cities and borders.

\footnotetext{
${ }^{36}$ EUROCITIES, 'EUROCITIES strategic framework 2014-2020: towards an EU urban agenda for cities' (2015),

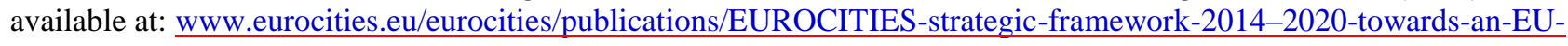
urban-agenda-for-cities-WSPO-9T2CS9 (accessed 15 March 2019).

${ }^{37}$ Ibid.

${ }^{38}$ EUROCITIES, 'EUROCITIES strategic framework 2014-2020: towards an EU urban agenda for cities' (2015), available at: www.eurocities.eu/eurocities/publications/EUROCITIES-strategic-framework-2014-2020-towards-an-EUurban-agenda-for-cities-WSPO-9T2CS9 (accessed 15 March 2019).

${ }^{39}$ EUROCITIES, 'Cooperation', available at: http://www.eurocities.eu/eurocities/forums/cooperation\&tpl=home (accessed 15 March 2019).

${ }^{40}$ EUROCITIES, 'About EUROCITIES', available at: http://www.eurocities.eu/eurocities/about_us (accessed 15 March 2019).

${ }^{41}$ Ibid.
} 
However, EUROCITIES' character as an interest group does not make it irrelevant to solidarity. Quite to the contrary, interest groups are normally characterised by a sense of solidarity. They share common interests and challenges, which they together attempt to promote and solve. To that extent, elements of transnational solidarity are present in the EUROCITIES endeavour, but appear to be retained largely in the relations between the cities and not to trickle down to the citizens, which the cities represent.

As a good example, EUROCITIES is involved in the 'Solidarity Cities' initiative on the management of the refugee crisis and on the integration of refugees. 'Solidarity Cities' was launched by the city of Athens under the framework of the EUROCITIES network, and is structured around four pillars: (i) information and knowledge exchange on the refugee situation in cities; (ii) advocating for better involvement and direct funding for cities on reception and integration of refugees; (iii) city-to-city technical and financial assistance and capacity building; and (iv) pledges by European cities to receive relocated asylum seekers. ${ }^{42}$

There seems to be a clear element of solidarity in the description of this concrete initiative in the field of refugees, not only as regards knowledge-sharing and common policies, but also as regards 'financial assistance' and the 'relocation of asylum seekers'. Here we can identify a clear commitment and willingness to bear costs in the form of sharing knowledge as well astechnical, financial, and capacity-building expertise. Interestingly, the described solidarity initiative concerns a field, which it has proven difficult to handle at the formal EU political level (namely, burdensharing among Member States in the field of asylum seekers).

\section{2) $U R B A C T$}

Another interesting cross-border cooperation between cities is URBACT. Unlike EUROCITIES, URBACT is a European Union creation, one of the Interreg initiatives under the European Territorial Cooperation programme, and part of the Union's regional and cohesion policy. URBACT has been conceived in the context of the EU's economic strategy 'Europe 2020', which seeks smart, sustainable, and inclusive growth. ${ }^{43}$ Despite its temporal limitations and nature as a programme, URBACT is structured with a degree of permanence and looks much more like an organisation, with its secretariat in Paris and National URBACT Points in most Member States.

\footnotetext{
${ }^{42}$ Solidarity Cities, 'About', available at: https://solidaritycities.eu/about (accessed 15 March 2019).

${ }^{43}$ URBACT, 'URBACT at a glance', available at: https://urbact.eu/urbact-glance (accessed 15 March 2019); European

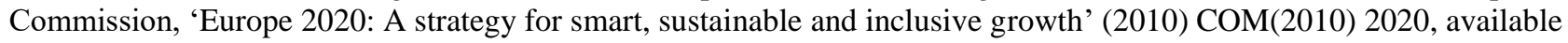
at: http://ec.europa.eu/eu2020/pdf/COMPLET\%20EN\%20BARROSO\%20\%20\%20007\%20-\%20Europe\%202020\%20\%20EN\%20version.pdf (accessed 15 March 2019).
} 
URBACT's main beneficiaries are cities from the EU Member States, Norway, and Switzerland. URBACT employs a broader notion of city than EUROCITIES, which covers 'cities, municipalities, towns (without limit of size), infra-municipal tiers of government, metropolitan authorities as well as organized agglomerations' ${ }^{44}$ Its other beneficiaries include 'local agencies, provincial, regional and national authorities; universities and research centers' ${ }^{45}$ As of January 2019, URBACT III had 415 beneficiaries. ${ }^{46}$ URBACT carries out three types of activities: transnational exchanges, capacity-building, and capitalisation and dissemination. ${ }^{47}$

'Since 2002, URBACT has provided alternative solutions to addressing key urban challenges by promoting sustainable integrated urban development through exchange and learning. URBACT supplies cities with tools and methods to develop strategies and solutions to high-priority urban issues. As these challenges are shared across the European Union (EU), URBACT is financed by the European Commission and contributes to the delivery of its strategy to prepare the EU economy for the next decade. URBACT does not finance physical investments, nor does it carry out pilot projects. Rather, URBACT uses resources and know-how to strengthen the capacity of cities to build solid strategies and action plans that respond to all the different kind of economic, environmental and societal challenges they are facing today. The main target participants of the programme include urban practitioners, city managers, elected representatives, stakeholders from other public agencies, the private sector and the civil society. ${ }^{48}$

Compared to EUROCITIES, URBACT is especially interesting in two aspects. First, URBACT has quite a strong focus on the inclusion of citizens as participants in the programme (see the quote above) - this is among others achieved through summer schools - and on engaging citizens in crossborder solidarity. URBACT for instance carried out a project on cross-border conurbations, which dealt with the challenges of developing inhabitants' feeling of belonging to a cross-border area and involving civil society within the cross-border public life. The project analysed how the European Grouping of Territorial Cooperation, which is today the only European legal tool able to establish a multi-level governance, can be a reference tool to support the governance of cross-border

\footnotetext{
${ }^{44}$ European Union, European Regional Development Fund, 'URBACT III operational programme' (2015) 11, available at: https://urbact.eu/sites/default/files/u iii op oct 2015.pdf (accessed 15 March 2019), p. 36.

45 Ibid.

${ }^{46}$ URBACT, 'List of URBACT III beneficiaries', available at: https://urbact.eu/files/list-urbact-iii-beneficiaries (accessed 15 March 2019).'

${ }^{47}$ URBACT, 'URBACT at a glance'.

${ }^{48}$ URBACT, 'URBACT III - 2016 citizens' summary', available at: https://urbact.eu/sites/default/files/air 2016 citizens summary.pdf (accessed 15 March 2019).
} 
conurbations. ${ }^{49}$ As an example of such a cross-border cooperation, the Öresund region is mentioned: $:^{50}$

'The example of the cooperation that is led within the Öresund, between Malmö (Sweden) and Copenhagen (Denmark), two cities linked by a bridge since 2000, has demonstrated, following the setting-up of an online forum dedicated to the citizens of the cross-border region, that $99 \%$ of them are interested in cross-border cooperation for very practical questions related to their daily lives (job ads, movie time schedule, cultural agenda...).'

While URBACT undoubtedly seeks to foster and facilitate cooperation between actual citizens (and not merely cities) across borders, one might ask whether the underlying motivation is to build solidarity between and among European citizens (unless solidarity is taken to mean pursuing the 'common' European economic objectives of smart, sustainable, and inclusive growth).

Nevertheless, given that the activities and programmes connect people across borders in sharing among others knowledge, it is certainly possible that the activities and programmes it facilitates create the space for solidarity-building through a commitment and a willingness to carry 'costs' across borders.

As indeed URBACT promotes on its homepage: 'We enable cities to work together to develop solutions to major urban challenges, reaffirming the key role they play in facing increasingly complex societal changes. ${ }^{51}$ Targeted challenges are in the areas of integrated urban development, the economy, the environment, governance, and inclusion.

URBACT is especially interesting in one more regard. In the URBACT III programme, crossborder implementation networks are established with regard to the size of the city:

'Cities of similar size which have already developed a strategy or an action plan to tackle a challenge gather in a network to jointly tackle the issue at stake. As partners in such networks, cities share experiences, problems and possible solutions, generating

\footnotetext{
${ }^{49}$ A. Decoville, F. Durand, and V. Feltgen, Opportunities of Cross-Border Cooperation between Small and Medium Cities in Europe (Luxembourg: Luxembourg Institute of Socio-Economic Research (LISER)/Department of Spatial Planning and Development - Ministry of Sustainable Development and Infrastructure, Luxembourg 2015).

${ }^{50}$ URBACT, 'EGTC Seminar: Involvement of Civil Society within Cross-Border Conurbations' (2017), available at: https://urbact.eu/egtc-seminar-involvement-civil-society-within-cross-border-conurbations (accessed 15 March 2019). 51 URBACT, 'URBACT at a glance', available at: https://urbact.eu/urbact-glance (accessed 15 March 2019).
} 
new ideas and learning from one another to manage the switch from theory to practice, from building an action plan to implementing it [bold inserted by us]. ${ }^{52}$

In the European context, this is significant, since 'Europe is characterised by a more polycentric and less concentrated urban structure compared to the USA or China'. ${ }^{53}$ Taking this into account, URBACT sets out to 'respect the diversity of European settlement system and will target all kind of European cities and towns including smaller and medium sized one which tend to have less capacity and fewer specialised staff' ${ }^{54}$ This fits nicely with our comments on how the size of cities matter and that we need transnational cooperation among cities based on size. Furthermore, the transnational solidarity elements in this cooperation among cities can be seen in the sharing of knowledge, experience, and solutions to common challenges. Together, the cities can generate new ideas.

\section{3) Twinning}

The town twinning movement started shortly after the end of World War II. The Council of European Municipalities and Regions (today, also a member of the prominent global network 'UCLG', which we will return to later in the chapter) has been at the forefront of advocating for the twinning movement. Initially, twinning partnerships were established between towns that had been divided due to war. ${ }^{55}$ Twinning partnerships blossomed again as Greece, Portugal, and Spain were preparing to join the European Union, as well as after the fall of the former communist regimes in Eastern Europe, which led to a new wave of accession to European Union membership. ${ }^{56}$ Non-EU countries such as Norway and Switzerland also participate. By 2010, the total number of twinning partnerships was estimated at over 20,000. ${ }^{57}$ Twinning takes place between cities of varying size, from small villages, to towns, counties, and cities proper.

\footnotetext{
52 URBACT, 'URBACT III - 2016 citizens' summary', p.3, emphasis added.

${ }^{53}$ European Union, European Regional Development Fund, 'URBACT III Operational Programme' (2015) 11, available at: https://urbact.eu/sites/default/files/u_iii_op_oct_2015.pdf (accessed 15 March 2019).

${ }^{54}$ Ibid.

55 Twinning, 'History', available at: http://www.twinning.org/en/page/history\#.XIxB7ChKhPZ (accessed 15 March 2019).

56 Ibid.

${ }^{57}$ Council of European Municipalities and Regions, 'Table showing the number of twinnings in wider Europe in 2010', available at: http://www.twinning.org/uploads/assets/news/Number\%20of\%20twinnings\%20in\%20Europe\%20in\%202010.pdf (accessed 15 March 2019). Note that the table inputs all twinning points, which is why the total figure is close to 40,000. Since we are looking at the number of partnerships entered into by two cities, the relevant figure is half of the total, that is, just under 20,000 .
} 
Intended to emulate the friendship, twinning is a commitment between two cities, based on mutual awareness, to cooperate on for example the arts, culture, sustainable development, social inclusion, and more. Active participation by the citizens is highlighted as key to a successful twinning partnership. Twinning partnerships are intended for the long-term, meaning they should survive political changes, and the partners should support one another in times of need (e.g. natural disasters). ${ }^{58}$ Given these underlying objectives, it is clear that the purpose is to establish transnational solidarity through a commitment and willingness to bear 'costs'. Notable examples include the city twinning projects that were set up between Western cities and South African townships in the 1980s, to show 'solidarity with the black population in South Africa in the fight against apartheid'. ${ }^{59}$

\section{B. Thematic cooperation initiatives}

Another group of initiatives were thematic in nature. Although the constraints of space did not permit a detailed analysis of all of them, a number are worth mentioning, for the sake of highlighting the breadth of initiatives. The European Association of Historic Towns and Regions, with its membership of over 1200 historic and heritage towns, cities, and regions in 32 European countries, was formed by the Council of Europe and seeks to 'promote the interests of historic towns and cities across Europe' through international cooperation, the sharing of experiences and good practices, and promoting 'vitality, viability and sustainable management' ${ }^{60}$ To the extent that there are elements of knowledge-sharing in the initiative, its solidarity potential is of a similar kind as that in EUROCITIES and URBACT. The same could be said for the European Alliance of Cities and Regions for the Inclusion of Roma and Travellers, which was launched in 2013. Set up by the Council of Europe's Congress of Local and Regional Authorities, the alliance includes 130 cities and regions from 29 countries. It aims to promote projects and policies for the inclusion of Roma and Travellers, and to fight anti-gypsyism, which it does through condemning hate speech against Roma and Travellers; recognising anti-gypsyism as a form of racism; enabling cooperation and the sharing of good practices for political engagement, lobbying, and advocacy; and working to improve the dialogue between local authorities, NGOs, as well as between Roma and Traveller

\footnotetext{
58 Twinning, 'A quick overview', available at: http://www.twinning.org/en/page/a-quick-overview\#.XIxDLChKhPa (accessed 15 March 2019).

${ }^{59}$ Pluijm and Melissen, 'City Diplomacy', p. 15.

${ }^{60}$ European Association of Historic Towns and Regions, 'Who are we?', available at: http://www.historictowns.org/about-us/ (accessed 15 March 2019).
} 
residents and the rest of the population. ${ }^{61}$ Here, the commitment to sharing expertise and good practices suggests burden-sharing in an effort to address a matter of common societal concern.

\section{1) The Covenant of Mayors}

The Covenant of Mayors is an example of a transnational cooperation initiative among cities on one specific topic. It is the world's largest movement for local climate and energy actions, bringing together 'thousands of local governments voluntarily committed to implementing EU climate and energy objectives... and achieving and exceeding the EU climate and energy targets' ${ }^{62}$ Gathering more than 7,000 local and regional authorities across 57 countries, and 'drawing on the strengths of a worldwide multi-stakeholder movement and the technical and methodological support offered by dedicated offices', its success 'quickly went beyond expectations'. ${ }^{63}$

This initiative is built on a transnational vision and on the desire for solidarity among cities as a means of implementing the EU's climate and energy objectives. The cities voluntarily enhance environmental, climate, and energy actions with a shared environmental goal.

\section{2) The European Charter for the Safeguarding of Human Rights in the City}

The European Charter for the Safeguarding of Human Rights in the City is an initiative through which European cities cooperate on the respect, protection, and fulfilment of human rights at the local level. It 'strives to make municipal administration more accessible and effective to city dwellers. It aims to improve the collective use of public space and to guarantee human rights for all.'

The cooperation started in Barcelona in 1998 in the framework of the Conference 'Cities for Human Rights', which was organised to commemorate the 50 Anniversary of the Universal Declaration of Human Rights: ${ }^{64}$

\footnotetext{
${ }^{61}$ European Alliance of Cities and Regions for the Inclusion of Roma and Travellers, 'About us', available at: http://www.roma-alliance.org/en/page/33-about-us.html (accessed 15 March 2019).

${ }^{62}$ Covenant of Mayors for Climate \& Energy, available at: https://www.covenantofmayors.eu/en/ (accessed 15 March 2019).

${ }^{63}$ Ibid.

${ }^{64}$ UCLG Committee on Social, Inclusion, Participatory Democracy and Human Rights, 'European Charter for the Safeguarding of Human Rights in the City' (United Cities and Local Governments), available at: https://www.uclgcisdp.org/en/right-to-the-city/european-charter (accessed 15 March 2019).
} 
'Hundreds of Mayors participated in the event and united their voice to call for a stronger political acknowledgement as key actors in safeguarding human rights. Participating cities adopted the "Barcelona Engagement", consisting of a roadmap to draft a political document aimed at fostering the respect, protection and fulfilment of human rights at local level. During the two proceeding years, the European Charter for the Safeguarding of Human Rights in the City was drafted as the result of a plural dialogue between European cities, civil society representatives and human rights experts. The draft was discussed and finally adopted in Saint-Denis in 2000.'

At the time of writing, the Charter had been signed by approximately 400 cities. This is an interesting initiative in several ways. Human rights conventions such as the European Convention of Human Rights are binding on the states. Municipalities are of course part of the state and when they execute administrative power they must comply with the conventions to which their nation states are contracting parties. Since human rights conventions are normally ratified by states, it might seem that compliance with human rights in municipalities is to a large extent a relationship between the state and its municipalities. However, in this initiative, municipalities across borders cooperate in order to promote compliance with human rights in cities across Europe. By so doing, the cities take upon themselves a shared responsibility for safeguarding human rights at the local level. Another observation in relation to this initiative is that the involved cities step into the arena as key actors in lifting and solving important, comprehensive, and complex societal challenges, which have traditionally been viewed as the responsibility of states. In a field such as human rights, where not all European countries have implemented all the UN conventions, there is even room for the cities to provide a better human rights protection than the state has provided, if they wish to do so. This could for instance be relevant in the field of disability rights, and the rights of woman and children. The described cooperation seems to satisfy the definition of transnational solidarity.

\section{Geographically delimited cooperation initiatives}

Several cooperation initiatives were delimited by geographic area. The Union of the Baltic Cities, for example, is a network of around 100 cities in the Baltic Sea region, drawn from the countries Denmark, Estonia, Finland, Germany, Latvia, Lithuania, Norway, Poland, Russia, and Sweden. Self-described as a 'voluntary, proactive network mobilizing the shared potential of its member cities, the Union works across seven Commissions, focusing on culture, inclusivity and health, planning, safety, prosperity, sustainability, and youth' ${ }^{65}$ A second example is the Council of

\footnotetext{
65 'Union of the Baltic Cities', available at: http://www.ubc.net/ (accessed 15 March 2019).
} 
Danube Cities and Regions, established in 1998, with a membership of around 40 cities and regions in the Danube region at the time of writing. In addition to highlighting its respect for democracy and human rights, the Council, in its mission statement, states that it is founded on the belief that powers between the state and regions should be apportioned 'in accordance with the principles of political decentralization and subsidiarity', and that 'functions should be exercised at the level as close to the citizen as possible'. ${ }^{66}$

\section{1) Nordic Safe Cities}

In the spirit of 'most different', Nordic Safe Cities stands out as an initiative with a strong agenda towards solidarity-building. Geographically limited to the Nordic countries (Denmark, Finland, Iceland, Norway, and Sweden), 25 cities and municipalities (as well as several organisations) across the Nordic participated in its activities in 2016-2017. The cooperation network is funded by the Nordic Council of Ministers, which also took initiative for its creation. It appeals to Nordic values, in particular to democracy, human rights, openness, trust, and tolerance. The focus is particularly on the prevention of radicalisation and violent extremism, which are considered both threatening to cities' safety and ability to be tolerant, as well as to challenge Nordic values as such. ${ }^{67}$

'Violent extremism is a fundamental challenge. Not only because of the immediate physical danger that it poses, but because it challenges our democracies and way of life. It challenges the very essence of the societies we have built - the trust in our citizens. A society closing its doors around itself is an excluding society where people become suspicious of each other's motives. It is a society where we ultimately become less tolerant to other people's ideas and convictions. Nordic Safe Cities is doing the opposite [Dagfinn Høybråten, Secretary General of the Nordic Council of Ministers]. ${ }^{68}$

Nordic Safe Cities has formulated 'six ambitions', focus areas, for its work on making cities safe and preventing 'radical and violence-promoting behaviour': safe urban spaces, a safe online sphere, strong families, safe public institutions, a strong youth engagement, and safe communities. ${ }^{69}$ It is also interesting to note that the network collaborates with the Radicalisation Awareness Network, set up by the European Commission (also known as 'RAN'), ${ }^{70}$ in an effort to scale up the Nordic

\footnotetext{
${ }^{66}$ Council of Danube Cities and Regions, 'Mission \& vision', available at: http://www.codcr.com/about-up/missionvision/ (accessed 15 March 2019).

${ }^{67}$ The Nordic Council of Ministers, 'The Nordic safe cities guide' (2017), available at: https://nordicsafecities.org/wpcontent/uploads/2017/03/nsc_guide_download.pdf (accessed 15 March 2019).

${ }^{68}$ Ibid., p. 6.

${ }^{69}$ Ibid., p. 9.

${ }^{70}$ European Commission, 'Radicalisation Awareness Network (RAN)' (Migration and Home Affairs), available at: https://ec.europa.eu/home-affairs/what-we-do/networks/radicalisation_awareness_network_en (accessed 15 March 2019).
} 
approach, and to share its knowledge and experiences with the wider Europe. ${ }^{71}$ Nordic Safe Cities is a collaboration based on a commitment and willingness to bear costs among the Nordic countries, and also involves knowledge-sharing.

\section{LINKING EUROPE TO THE REST OF THE WORLD}

Though our focus in this chapter has primarily been on solidarity initiatives among cities in the European Union and the wider geographical space of Europe, we will now provide a few examples of how solidarity among cities goes beyond the EU and Europe. One might say that this is not surprising, since many of the major challenges of our time are global rather than regional or local. Thus, for example, C40 is a 'network of the world's megacities committed to addressing climate change'. Connecting (the mayors of) '94 of the world's megacities to take bold climate action', C40 is present in cities which together house over 700 million citizens. C40 convenes networks, conducts programmes on barriers to climate action (e.g. inclusivity, finance, and planning), carries out research, and develops tools and frameworks for action based on its research. ${ }^{72}$ Another notable initiative is the International Cities of Refuge Network (hereinafter, 'ICORN'), which offers 'shelter to writers and artists at risk, advancing freedom of expression, defending democratic values and promoting international solidarity'. ICORN member cities offer long-term shelter to those 'at risk as a direct consequence of their creative activities'. Currently more than 70 cities have joined the network. ${ }^{73}$ While ICORN is not an initiative involving cities coming together to work on a shared problem they face in their respective locality, it is an initiative that brings cities together because of their shared belief in the very notion of transnational solidarity, in particular as it pertains to respect for human dignity, life, and the protection of individuals' freedom of expression.

\section{1) United Cities and Local Governments}

By far the most prominent on the global scene is United Cities and Local Governments (hereinafter, 'UCLG'). UCLG seeks to represent and defend the interests of local governments on the world stage, including in United Nations and other global fora. To that extent, it is similar in kind to EUROCITIES. Created in 2004, after local and regional authorities decided to 'unite their voices

\footnotetext{
${ }^{71}$ Nordic Safe Cities, 'Nordic safe cities in Europe', available at: https://nordicsafecities.org/local-concepts-2/nordicsafe-cities-europe/ (accessed 15 March 2019).

${ }^{72}$ C40, available at: https://www.c40.org/ (accessed 15 March 2019).

${ }^{73}$ International Cities of Refuge Network (ICORN), 'ICORN cities of refuge', available at: https://www.icorn.org/icorn-cities-refuge (accessed 15 March 2019).
} 
before the international community' ${ }^{74}$ the UCLG network comprised 240,000 towns, cities, regions and metropolises in 140 nation states, representing 5 billion people or $70 \%$ global population by $2015 .^{75}$

By supporting international cooperation between cities, and facilitating networks, partnerships and learning to build the capacities of local governments, UCLG works towards its mission statement:

'To be the united voice and world advocate of democratic local self-government...'

UCLG has a decentralised structure, with nine sections. Seven of these are regional, including the prominent European section, namely the Council of European Municipalities and Regions (hereinafter, 'CEMR'), ${ }^{76}$ whose work we have already mentioned in relation to two of the abovediscussed initiatives. The first is the Twinning movement, of which the CEMR was the brainchild. The second is the European Charter for the Safeguarding of Human Rights in the City, which the Committee on Social Inclusion, Participatory Democracy and Human Rights of the UCLG was involved in and promoted. Eleven years later, in 2011, UCLG's World Council adopted a global equivalent, the Global Charter-Agenda for Human Rights in the City. ${ }^{77}$ To relate to an introductory discussion, the UCLG was actively involved in advocating for SDG 11 on sustainable cities, ${ }^{78}$ and continues to be active in this field, working along with UNDP and UN-Habitat on a toolkit for 'localizing the SDGs'. ${ }^{79}$

\section{2) The Strong Cities Network}

This network among cities from all over the world is a very good example of a common global initiative aiming at preventing and solving one of the most pressing challenges of our times, namely terrorism attacks. ${ }^{80}$ This is of course a serious matter, which is normally dealt with by national state institutions such as the police, intelligence service, and foreign ministry - in cooperation with other

\footnotetext{
${ }^{74}$ United Cities and Local Governments (UCLG), 'Who are we?', available at: https://issuu.com/uclgcglu/docs/uclg_who_we_are (accessed 15 March 2019). 
states. In the Strong Cities Network, however, cities from all continents are attempting to solve a global challenge: ${ }^{81}$

'Launched at the United Nations in September 2015, the Strong Cities Network (hereinafter, 'SCN') is the first ever global network of mayors, municipal-level policy makers and practitioners united in building social cohesion and community resilience to counter violent extremism in all its forms.

Led by ISD ${ }^{82}$ and comprised of more than 120 cities, the SCN builds collaboration between mayors, political actors and frontline teams to tackle polarisation, hate and violence in local communities in every major global region. The network catalyses, inspires and multiplies community-centric approaches and action to counter violent extremism through peers learning and expert training. It operates with a set of fundamental principles, agreed by all members, that protect and promote human rights and civil liberties in all aspects of its work to prevent violent extremism [bold inserted by authors].'

This is a good example of a network that aims at building transnational solidarity globally.

\section{CITIZEN-DRIVEN INITIATIVES}

Finally, it should be mentioned that not only cities take transnational solidarity initiatives. Citizens also start such initiatives, which are typically less formal and have a shorter lifetime. An interesting example is 'Venligboerne', which is the Danish group created in 2013 in response to the migration and refugee flows that reached Europe during this period. ${ }^{83}$ While some citizens and politicians were worried and/or critical towards migrants and refugees coming to Denmark, 'Venligboerne' decided to create a positive, open, and inclusive alternative. Their key idea was to meet other people with kindness, curiosity, and respect. Interestingly, transnational solidarity is reflected in two ways in this initiative. First, a form of transnational solidarity with the migrants and refugees is clearly expressed in the initiative. Second, 'Venligboerne' also exists in other European countries such as in Norway, Sweden, Germany, the United Kingdom, Greece, Italy, and France. Hence, there is a degree of transnational solidarity among the different national groups working under this initiative. A further and important reflection is that 'Venligboerne' is an example of an initiative, which has sub-groups all over Denmark, and both big and small cities in its steering committee. This shows that with the right cause and aim, it is possible to create a solidarity that breaks down the big city vs. small city divide and which at the same time is based on transnational solidarity.

\footnotetext{
${ }^{81}$ Ibid, emphasis added.

${ }^{82}$ Institute for Strategic Dialogue, available at: www.isdglobal.org/ (accessed 15 March 2019).

${ }^{83}$ Venligboerne, available at: http://www.venligboerne.org/ (accessed 15 March 2019).
} 


\section{CONCLUSION}

Despite their differences, the analysed case studies on intercity cooperation all turned out to be geared towards transnational solidarity in some form. The involved actors, commitments, and costs differed from case to case but they all fell within our definition of transnational solidarity. This shows how widespread such intercity cooperation is and the broad spectrum of topics it involves. We have not attempted to measure the actual impact of such initiatives; however, it is clear that we are facing an increasing trend of 'bonding' between European cities and beyond. While this trend might to some extent reflect that cities and their inhabitants are not satisfied with how the EU (and nation states) are handling contemporary challenges, the created transnational bonds, might still strengthen Europe's emotional coherence and in this way provide the EU with a stronger basis. It is noteworthy that cities in Europe and beyond are joining forces in a common quest to take responsibility for and attempt to solve global challenges such as environmental problems and terrorism threats. Serious problems, which are normally solved by states alone and in cooperation for instance in the EU or the UN.

Many big cities are bigger than small states. This makes them not only powerful political players, but it also strengthens the feasibility of their ambitions as actors with the potential to contribute to the solution of some of the most pressing challenges facing humanity in the $21^{\text {st }}$ century. Many of the case studies also seem to reflect that solidarity is definitely no longer a national issue. Big cities seek other big cities with the same identity and challenges. Cities - including smaller cities - around the Arctic zone or the Baltic Sea, which for instance share geographical, geopolitical, and environmental characteristics, also seek each other. There seems to be a greater awareness of other people across borders, who live under similar conditions, and a shared belief that together such transnational groups can actually solve problems and benefit from each other. Obviously, this seems to reflect a new kind of transnational bond and solidarity, which in many of the studied cases appear outside the EU treaties and other state-created legal instruments. In some cases, we see an interplay between the city-led initiatives and the European Union, either through EU funding or when cities try to influence EU policy in relevant fields. Finally, there are also initiatives, which were originally initiated by the EU to promote cooperation among cities in the EU. Examples of the latter include the European Capitals of Culture initiative, which among others aims at 'increasing the European 
citizen's sense of belonging to a common cultural area' ${ }^{84}$ and the European Green Capital Award, 'which recognises and rewards local efforts to improve the environment, the economy and the quality of life in cities' ${ }^{85}$ The EU seems aware that cooperation among cities might strengthen a feeling of transnational European solidarity.

Ironically, such a new transnational city-solidarity also seems to hold the potential to split Europe into big and small cities. This split at the national level is already a reality in many Member States. Transnational solidarity between alike cities might build cross-border solidarity and identity however, it might also strengthen the cultural and political gap between cosmopolitan cities and more remote areas. While it is conceivable that this form of transnational solidarity, which transgresses geographical, legal, and political borders, might emerge, it is also conceivable that new, physically invisible borders, which do not follow any geographical, legal, or political formalities, might appear within Member States. This development must be seen in light of the mentioned citizen-led initiative 'Venligboerne', which illustrated the potential for uniting citizens from big cities and small cities across countries and across borders in solidarity - in this case, in solidarity with migrants and refugees from countries far from Europe. Another example could be the recent protest marches demanding a political reaction to the environmental challenges by school children from all over Europe, originally sparked by a Swedish school girl, Greta Thunberg. Such examples seem to show a positive potential for a transnational solidarity, which transgresses all borders: legal, political, geographical, and cultural - within and across states.

\footnotetext{
${ }^{84}$ European Commission, 'European capitals of culture', available at: https://ec.europa.eu/programmes/creativeeurope/actions/capitals-culture_en (accessed 15 May 2019).

${ }^{85}$ European Commission, 'European green capital', available at:

http://ec.europa.eu/environment/europeangreencapital/about-the-award/policy-guidance/ (accessed 15 May 2019).
} 